\title{
Post-harvest treatments for controlling crown rot disease of Williams banana fruits (Musa acuminata L.) in Egypt
}

\author{
Abd-Alla MA, El-Gamal NG, El-Mougy NS and Abdel-Kader MM*
}

Department of Plant Pathology, National Research Centre, 12622 Giza, Egypt

Abd-Alla MA, El-Gamal NG, El-Mougy NS, Abdel-Kader MM 2014 - Post-harvest treatments for controlling crown rot disease of Williams banana fruits (Musa acuminata L.) in Egypt. Plant Pathology \& Quarantine 4(1), 1-12, Doi 10.5943/ppq/4/1/1

\begin{abstract}
Fusarium semitectum was isolated at high frequency from collected banana cultivar "Williams" showing crown rot symptoms from commercial markets. The inhibitory effect in vitro of tested essential oils on mycelium growth was higher than on conidium germination of $F$. semitectum. Complete inhibition of fungal growth and spore germination was recorded at the concentration of $1.0 \%$ of tested cinnamon and bitter almond oils. Under storage conditions, artificially inoculated bananas showed reduction in both crown rot disease incidence and severity when treated with cinnamon, thyme bitter and sweet almond oils. Complete reduction (100.0\%) of crown rot disease incidence of banana fruits was recorded at the concentration of $4.0 \%$ of applied cinnamon and thyme oils, followed by sweet almond and bitter almond oils which they reduced disease incidence by 87.1 and $78.7 \%$, respectively. Stored bananas treated with cinnamon, bitter and sweet almond oils showed no significant differences compared to the control with respect to odour, flavour, taste and overall acceptability. Hence cinnamon, thyme, bitter and sweet almond oils treatment developed during the current study without affecting the organoleptic properties recommended as a safe and cost-effective commercial method for treating bananas to control crown rot disease.
\end{abstract}

Key words - Colletotricum musae - fungal growth reduction - plant oils - stored fruits

\section{Introduction}

Crown rot of dehanded banana is a major cause of losses during storage and marketing of banana and considered as one of the most serious and frequent postharvest and post-packaging diseases (Khan et al. 2001). All commercial cultivars of desert bananas are known to be susceptible to crown rot. Crown rot, incited by a complex of fungi, is a major cause of postharvest losses in banana. Fusarium semitectum, Colletotrichum musae and C. gloeosporioides were identified as the major crown rot causing fungi in Sri Lanka (Indrakeerthi \& Adikaram 2011). They added that Musicillium theobromae and Botryodiplodia theobromae are also associated with the disease. Moreover, many fungi have been reported to be associated with banana crown rot, i.e. Penicillium corylophilum, Alternaria triticina, Cladosporium oxysporum, Acremoniums p., Fusarium spp., Bipolaris sp. and Eupenicillium sp. (Jones 1991) The infection takes place at the exposed surface of the crown. Usually the rot is confined to the crown but at advanced stages it spreads into the 
pedicels of the fingers. After severe infections, whitish fungal mycelia and reproductive bodies appear on the rotted crown, finger stalks and finally on the fingers (Griffee \& Burden 1976).

Application of systemic fungicides is the most common practice for commercial control of banana crown rot (Shillingford 1976, Cox 1996, Lassois et al. 2008). Although synthetic fungicides have provided effective control of major postharvest diseases, their application may be harmful to human health and the environment and they become ineffective after prolonged use. Attempts have been made towards crown rot control through cultural, physical and biological (Lassois et al. 2008) methods as an alternative to synthetic fungicides (Dionisio \& Natsuaki 2007). One of such alternative is the use of natural plant protectants with pesticide activity, as well as they tend to have low mammalian toxicity, less environmental effects and wide public acceptance (Paster et al. 1995, Don- Pedro 1996, Liu \& Ho 1999, Hamilton-Kemp et al. 2000, Paranagama et al. 2002, Ranasinghe et al. 2005). Essential oils are complex volatile compounds produced indifferent plant parts, which are known to have various functions in plants including conferring pest and disease resistance (Goubran \& Holmes 1993). The complexity in essential oils is due to terpene hydrocarbons as well as their oxygenated derivatives, such as alcohols, aldehydes, ketones, acids and esters (Wijesekara et al. 1997). Previous research trials indicated that the essential oil of Ocimum basilicum oil (basil oil) was fungicidal against the banana crown rot fungal pathogens - Colletotrichum musae, Fusarium proliferatum and Lasiodiplodia theobromae at a low concentration $0.08 \%$ (v/v) (Anthony et al, 2004). An emulsion spray of Indian sweet basil oil (Ocimum basilicum) when used at $0.16 \%$ $(\mathrm{v} / \mathrm{v})$ was effective in controlling crown rot of Embul banana without adversely affecting the organoleptic and physicochemical properties (Anthony et al. 2003). Cinnamon and clove essential oil could be used as alternative post-harvest treatments on banana. Banana treated with essential oil is chemically safe and acceptable to consumers (Ranasinghe et al. 2002).

Essential oils of Cinnamomum zeylanicum (cinnamon), Menthapiperita (peppermint), Ocimumbasilicum (basil), Origanum vulgare (origanum), teloxysambrosioides (the flavoring herb epazote), Syzygium aromaticum (clove), and Thymus vulgaris (thyme) caused a total inhibition of fungal development on maize kernels (Montes-Belmont \& Carvajal 1998).

Post-harvest treatments using essential oils may have relatively high acceptance, especially by consumers in Egypt because of consumer preference for the use of natural plant products rather than synthetic fungicides to control decay. The objective of the present study was to determine whether the commercial essential oils of cinnamon, thyme, bitter and sweet almond had any activity against the fungi causing crown rot disease of Williams bananas and, if so, to develop cost-effective and safe sprays could control post-harvest disease incidence, without adversely altering its organoleptic properties such as taste, odor and flavour.

\section{Materials and Methods}

\section{Source of materials}

Mature green apparently healthy Banana fruits (Musa acuminataL.) cultivar "Williams" of uniform sizes collected from different orchards located at Giza, Qualubia, Monifia and Behiera governorates were used for the experiments described in this work.

Commercial essential oils of cinnamon (a.i. cinnamic, aldehyde, 70-85\%), thyme (a.i. thymol, 60\%), bitter almond oil and sweet almond oil were used in the present work. Both sweet and bitter almonds have similar chemical composition and contain 35-55\% fixed oil. The only difference appears to be the presence of amygdalin (3-4\%) in bitter almond and its absence or presence in trace amounts in sweet almonds. Other constituents reported to be present in sweet and/or bitter almonds include protein (18-25\%); emulsin; prunasin $(0.005 \%$ in bitter almond); daucosterol, and other sterols (e.g., sitosterol, citrostadienol, 24-methylene-cycloartanol); calcium oxalate; tocopherols (mostly $\alpha$ ); trace amounts of vitamins A, B complex, and E; and amino acids, including glutamic acid, aspartic acid, and arginine. Essential oils used in the study were obtained from Chemical Industrial Development Company (CID), Egypt. 


\section{Fungal isolation and pathogenicity}

Crowns of banana cultivar "Williams" showing crown rot symptoms were collected from commercial markets located at previous stated governorates. The banana fruits were surface disinfected with $2 \%$ sodium hypochlorite for $3 \mathrm{~min}$, then rinsed with tap water, and air-dried. The disinfected crowns were stored in the laboratory in separate moist chambers at room temperature $\left(26-28^{\circ} \mathrm{C}\right)$. The development of crown rot was visually examined for fungal appearance. Infected tissue segments were transferred onto potato dextrose agar (PDA) plates and incubated at $26-28^{\circ} \mathrm{C}$. Fungal colonies that appeared were sub-cultured and identified according to the key and description of Barnett \& Hunter (1972) and Sutton (1980).

The pathogenic ability of the isolated fungi was performed under laboratory conditions. Dehanded banana fruits were surface disinfected with $2 \%$ sodium hypochlorite for 3 min, rinsed with tap water, and air-dried, then inoculated individually with each isolated fungal species. Under aseptic conditions, banana crowns were artificially inoculated by applying $200 \mu$ Lof a previously prepared conidial suspensions $\left(10^{6}\right.$ per $\left.\mathrm{mL}\right)$ of each tested fungal isolates on each freshly exposed crown tissue using a clean soft paint brush. Another set was treated with sterile distilled water and another untreated set served as controls. Three hands for each particular treatment were used. The inoculated banana fruits were kept in a moist chamber at room temperature for 7-10 days and then examined for singns of crown rot. The percentage of crown rot incidence was calculated as a number of infected fingers relative to the whole fingers in each banana hand.

\section{In vitro screening of essential oils against growth and spores germination of $F$. semitectum}

The inhibitory effect of cinnamon, thyme, bitter and sweet almond oils against growth and spores germination of $F$. semitectum, the main pathogen of banana crown rot disease, was evaluated under laboratory conditions. Emulsified stocks at high concentration of tested essential oils were prepared by dissolving in sterilized distilled water. A few drops of the emulsifier Tween 80 (Sigma Co.) were added to essential oil volumes. The tested concentrations were $0.125,0.25,0.50$ and $1.0 \%$. Different volumes of the essential oils emulsion were added to conical flasks containing 100 $\mathrm{ml}$ of sterilized PDA medium before its solidification to obtain the proposed concentrations. The supplemented media were poured into Petri-dishes $(9 \mathrm{~cm})$ about $20 \mathrm{ml}$ each. PDA plates free of essential oils were also prepared as control. Five plates were used as replicates for each particular treatment as well as control. Discs ( $5 \mathrm{~mm}$ diameter) of cultures of $F$. semitectum were placed onto the centre of Petri dishes with PDA, incubated at $25+2^{\circ} \mathrm{C}$, until fungal growth in the control filled the whole Petri dish, then all treatments were examined. Reduction in mycelial growth was calculated relative to the growth in the control treatment. The percentage of mycelial inhibition was calculated by the following formula:

Mycelial inhibition $(\%)=\frac{\mathrm{dc}-\mathrm{dt} \times 100}{\mathrm{dc}}$

Where:

$\mathrm{dc}=$ mean colony diameter of control sets

$\mathrm{dt}=$ mean colony diameter of treatment sets

The inhibitory effect of oils against conidial germination was performed. F. semitectum grown on PDA at $25 \pm 2^{\circ} \mathrm{C}$ until abundant conidium production was evident. Conidia were harvested by scraping the surface of the colonies with a spatula, transferred to sterilized distilled water and filtered through nylon mesh. All spore solutions were adjusted with sterile water to give a spore concentration of $10^{6}$ spores per milliliter. Aliquots of $100 \mu \mathrm{L}$ of the fungal spore suspension were transferred to glass tubes $(180 \times 16 \mathrm{~mm})$ containing $5 \mathrm{~mL}$ sterilized distilled water, then the tested essential oils emulsions were added individually to each tube to achieve the proposed concentration. All tubes were left for $6 \mathrm{~h}$, then shaken using a magnetic stirrer for $5 \mathrm{~min}$. One $\mathrm{ml}$ of each test tube was dispensed into Petri dish and about $20 \mathrm{ml}$ of semi-solidifying sterilized PDA were poured into the inoculated plates and rotated gently to ensure equal distribution of the fungal inocula. Fungal 
cell suspension free from essential oils was used as control. The reduction of colony numbers in the oil treatments in percent to those in the control treatments was noted. All plates were incubated for $72 \mathrm{~h}$ and then examined. All treatments consisted of three replicates, and experiments were repeated three times.

\section{In vivo efficacy of essential oils treatments against crown rot disease incidence and severity during storage}

A bunch of mature unripe banana fruits was de-handed by cutting through the crown very close to the main stalk. Before treatments, banana bunches were de-handed using a clean, sharp knife. The banana hands were washed with running tap water and kept on a layer of 3-4 clean tissues in order to drain off the excess water, then surface sterilized with $0.1 \%$ sodium hypochlorite solution and again washed with distilled water then left for air-dried onto filter paper prior to use. Aliquots $(200 \mu \mathrm{L})$ of each of cinnamon, thyme, bitter and sweet almond oils at concentrations of $1.0,2.0$ and $4.0 \%$ were applied individually onto the cut surface of the crown of 6 hands using a fine paint brush. One set treated with sterile distilled water and another untreated set served as controls. Thereafter, treated banana crowns were artificially inoculated by applying $200 \mu \mathrm{L}$ of a previously prepared suspension $\left(10^{6} / \mathrm{mL}\right)$ of $F$. semitectum conidia on each freshly exposed crown tissue using a clean soft paint brush. All sets of treated and untreated banana fruits were packed into cardboard boxes at the rate of $1 \mathrm{~kg} / \mathrm{box}$. The boxes of each treatment were placed into a mesh plastic basket $(40 \times 30 \times 15 \mathrm{~cm})$. Three boxes as replicates were used for each particular treatment as well as control. All baskets were stored at room conditions (temperatures of $20-23^{\circ} \mathrm{C}$ and relative humidity of $70-85 \%$ ). The storage period was 14 days. The percentage of crown rot incidence was recorded at the end of the storage period. The development of crown rot symptoms (disease severity) was observed and the extent of disease was assessed in percent by using a scale based on the depth of the crown infected from the surface extended to the finger stalks (distance between the crown surface and the finger stalks). This experiment was repeated twice.

\section{Organoleptic properties}

At the table ripe stage, bananas were evaluated for their sensory properties of treated and control samples by trained taste panelists. A questionnaire was used to record the data and taste, odour, flavour and overall acceptability were evaluated by the taste panel using a scale of zero to $100(1=0-25=$ Poor, 2=25-50= Fair, 3=50-75= Good and 4=75-100=Excellent $)$ after Sarananda and Wijeratnam (1994). Zero indicated off-taste, off-flavour, and the absence of banana characteristic and therefore non-acceptability and 100 indicated characteristic banana flavour, odour, taste and high acceptability.

\section{Statistical analysis}

Tukey test for multiple comparisons among means was utilized (Neler et al. 1985).

\section{Results and Discussion}

\section{Fungal isolation and pathogenicity}

Collected banana cultivar "Williams" showing crown rot symptoms from commercial markets revealed several fungal isolates.

The most frequently isolated fungi were Fusarium semitectum $(74.6 \%)$ followed by Colletotrichum musae (22.1\%), Lasiodiplodi atheobromae (21.4\%), Nigrospora sphaerica (10.9\%), Alternaria alternata (9.3\%) and Rhizopusstolonifer (3.9\%). Fusarium semitectumwas most frequently isolated from all locations, i.e. Giza, Qalubia, Menofyia and Beheira as a range between 75.5-80.0\%. Colletotrichum musae was frequently isolated at Menofyia (40.5\%). A lower frequency was recorded for samples collected from Giza governorate namely $33.3 \%$ for $L$. theobromae, $30.1 \%$ for N. sphaerica and 16.5 and $10.0 \%$ for A. alternata and Rh. stolonifer, respectively. Our findings conform to the reported causal fungi of banana crown rot disease in the 
literature. Fusarium spp., including F. semitectum, C. musae and L. theobromae have been reported as primary causes of crown rot in many countries (Stover 1972, Wallbridge \& Pinegar 1975, Griffee 1976, Griffee \& Burden 1976, Wallbridge 1981, Knight 1982, Slabaugh \& Grove 1982, Finlay \& Brown 1993). Other fungi have been associated occasionally with crown rot disease (Meredith 1971, Johanson \& Blazquez 1992). Other fungi such as Cephalosporium sp., Ceratocystis paradoxa and Musicillium theobromae that have been reported to play an important as causal agents of crown rot in other countries (Lukezic et al. 1967, Wallbridge \& Pinegar 1975, Griffee 1976, Shillingford 1977, Wallbridge 1981, Knight 1982, Slabaugh \& Grove 1982, Finlay \& Brown 1993) were not isolated during this study.

Furthermore, data in Table (1) reveal that the isolated fungus $F$. semitectum showed significant ability to induce crown rot disease incidence to banana cultivar "Williams" followed by C. musae under laboratory conditions. On the other hand, no crown rot disease symptoms were observed in banana fruits inoculated with $L$. theobromae, A. alternate, $N$. sphaerica, and $R h$. stolonifer. Artificial inoculation of crowns with $F$. semitectum and $C$. musae produced typical crown rot symptoms in $93.3 \%$ crowns. This study suggests that $F$. semitectum could be the main pathogen causing crown rot in Egypt. Colletotrichum musaeis also an important pathogen as it alone produced crown rot at a frequency of $63.3 \%$. In this concern, Fusariumsemitectumwas one of the most common species of Fusarium recovered from banana. Fusarium species have been isolated from lesions of banana fruits collected from markets in the USA and Italy (Vesonder et al. 1995) and were the most predominant species recovered from banana samples commercially available in Italy and Spain (Jimenez et al. 1993). In addition to banana fruit rot, F. semitectum also caused crown rot and fungal scald of banana (Jones and Slabaugh 1998). Moreover, Indrakeerthi \& Adikaram (2011) reported that crown rot symptoms were observed in all banana crowns artificially inoculated with a mixed suspension of conidia of $F$. semitectum, $C$. gloeosporioides and $C$. musae, at different frequencies within 3-6 days. Fruits had fully ripened on the 5th day. The average crown rot was $96.8 \%$ on the 8th day and the controls also had an average of $42.2 \%$ crown rot. $F$. semitectum, C. gloeosporioides and C. musae could be re-isolated from all artificially inoculated crowns at a frequency of $100 \%$.

Table 1 Ability of different fungi to induce banana crown rot disease under artificial inoculation conditions in vitro

\begin{tabular}{ll}
\hline Fungal isolate & $\begin{array}{l}\text { Crown rot } \\
\text { incidence }(\%)\end{array}$ \\
\cline { 2 - 2 } Fusarium semitectum & $93.3 \mathrm{a}$ \\
Colletotrichum musae & $63.3 \mathrm{~b}$ \\
Lasiodiplodia theobromae & $0.0 \mathrm{c}$ \\
Alternaria alternate & $0.0 \mathrm{c}$ \\
Nigrospora sphaerica & $0.0 \mathrm{c}$ \\
Rhizopus stolonifer & $0.0 \mathrm{c}$ \\
Control & $0.0 \mathrm{c}$ \\
\hline
\end{tabular}

Figures in each column with the same letter are not significant difference $(\mathrm{P} \leq 0.05)$

\section{In vitro screening of essential oils against growth and spores germination of $F$. semitectum}

The effect of different concentrations of some essential oils on mycelial growth of $F$. semitectumand its spore germination was presented in Tables 2 and 3. The inhibitory effect of tested essential oils on mycelial growth was higher than their effect on spore germination. Results presented in Table (2) indicated that, cinnamon and bitter almond oils show a highly significant reduction in the mycelial growth at the low concentration of $0.125 \%$ by 63.0 and $43.8 \%$, respectively. This reduction increased gradually by increasing the concentration of the two essential oils to reach complete fungal growth inhibition at the concentration of $1.0 \%$. Also, mycelial growth reduced by increasing the concentrations of the essential oils in the growth medium. At the highest concentration of $1.0 \%$, thyme oils caused a reduction of $71.2 \%$ in mycelial growth, followed by $63.0 \%$ after sweet almond oil treatment. 
Table 2 Reduction (R) of growth diameter (L) of $F$. semitectum in response to different concentrations of some plant essential oils in vitro

\begin{tabular}{lccccccccc}
\hline Essential oils & \multicolumn{7}{c}{ Essential oils concentrations (\%) } \\
& \multicolumn{2}{c}{$\mathbf{0 . 1 2 5}$} & \multicolumn{2}{c}{$\mathbf{0 . 2 5}$} & \multicolumn{2}{c}{$\mathbf{0 . 5 0}$} & \multicolumn{1}{c}{$\mathbf{1 . 0}$} \\
& $\mathbf{L ~ ( m m )}$ & $\mathbf{R} \%$ & $\mathbf{L}(\mathbf{m m})$ & $\mathbf{R \%}$ & $\mathbf{L}(\mathbf{m m})$ & $\mathbf{R} \%$ & $\mathbf{L}(\mathbf{m m})$ & $\mathbf{R} \%$ \\
\hline Thyme & $65.2 \mathrm{~b}$ & 27.5 & $52.1 \mathrm{c}$ & 42.1 & $42.1 \mathrm{c}$ & 53.2 & $25.9 \mathrm{c}$ & 71.2 \\
Cinnamon & $33.3 \mathrm{~d}$ & 63.0 & $24.5 \mathrm{e}$ & 72.7 & $72.7 \mathrm{~b}$ & 19.2 & $00.0 \mathrm{~d}$ & 100 \\
Bitter almond & $50.5 \mathrm{c}$ & 43.8 & $38.1 \mathrm{~d}$ & 57.6 & $57.6 \mathrm{c}$ & 36.0 & $00.0 \mathrm{~d}$ & 100 \\
Sweet almond & $66.8 \mathrm{~b}$ & 25.7 & $45.5 \mathrm{c}$ & 49.4 & $49.4 \mathrm{c}$ & 45.1 & $33.3 \mathrm{c}$ & 63.0 \\
Control & $90.0 \mathrm{a}$ & 0.0 & $90.0 \mathrm{a}$ & 0.0 & $90.0 \mathrm{a}$ & 0.0 & $90.0 \mathrm{a}$ & 0.0 \\
\hline
\end{tabular}

Figures in each column with the same letter are not significant difference $(\mathrm{P} \leq 0.05)$

A similar trend in a lower extend was also observed for the tested essential oils at different concentrations in spore germination of $F$. semitectum (Table 3). At the concentration of $0.125 \%$ Cinnamon and bitter almond oils show the highest reduction in spore germination recorded as 52.2 and 39.5\% comparing withthyme and sweet almond which recorded as 28.4 and 20.1\%, in respective order. Meanwhile, the highest reduction in the percentages of spore germination were recorded as 85.8, 78.2, 68.0 and 62.8 at the concentration of $1.0 \%$ of cinnamon, bitter almond, thyme and sweet almond, respectively.

Essential oils display a strong fungicidal activity against many fungi, which include some crown rot pathogens such as $F$. semitectumand $C$. musae.

Similar results were also reported concerning the efficacy of essential oils as antifungal inhibitors. Akgul \& Kivanc (1988) studied the antifungal activity of selected Turkish spices essential oils (black cumin, coriander, cumin, dill, laurel, oregano, parslely, spearmint, white mustard, oregano, thymol and carvacrol) on some food-borne fungi.

Table 3 Average percent (\%) of spore germination theF.semitectum the causal of crown rot disease of banana fruits in response to different concentrations of some plant essential oils in vitro

\begin{tabular}{|c|c|c|c|c|c|c|c|c|}
\hline \multirow[t]{3}{*}{ Essential oils } & \multicolumn{8}{|c|}{ Essential oils concentrations (\%) } \\
\hline & \multicolumn{2}{|c|}{0.125} & \multicolumn{2}{|c|}{0.25} & \multicolumn{2}{|c|}{0.50} & \multicolumn{2}{|l|}{1.0} \\
\hline & $\begin{array}{l}\text { Spore } \\
\text { germination }\end{array}$ & $\mathbf{R} \%$ & $\begin{array}{l}\text { Spore } \\
\text { germination }\end{array}$ & $\mathbf{R} \%$ & $\begin{array}{l}\text { Spore } \\
\text { germination }\end{array}$ & $\mathbf{R} \%$ & $\begin{array}{l}\text { Spore } \\
\text { germination }\end{array}$ & $\mathbf{R} \%$ \\
\hline Thyme & $61.1 \mathrm{~b}$ & 28.4 & $51.1 \mathrm{~b}$ & 40.1 & $43.3 \mathrm{~b}$ & 49.2 & $27.3 \mathrm{c}$ & 68.0 \\
\hline Cinnamon & $40.5 \mathrm{~d}$ & 52.2 & $31.3 \mathrm{~d}$ & 63.3 & $21.1 \mathrm{~d}$ & 75.2 & $12.1 \mathrm{~d}$ & 85.8 \\
\hline Bitter almond & $51.6 \mathrm{c}$ & 39.5 & $42.2 \mathrm{c}$ & 50.5 & $31.4 \mathrm{c}$ & 63.2 & $18.6 \mathrm{~d}$ & 78.2 \\
\hline Sweet almond & $68.2 \mathrm{~b}$ & 20.1 & $55.1 \mathrm{~b}$ & 35.4 & $43.6 \mathrm{~b}$ & 48.9 & $31.7 \mathrm{~b}$ & 62.8 \\
\hline Control & $85.4 \mathrm{a}$ & 0.0 & $85.4 \mathrm{a}$ & 0.0 & $85.4 \mathrm{a}$ & 0.0 & $85.4 \mathrm{a}$ & 0.0 \\
\hline
\end{tabular}

Figures in each column with the same letter are not significant difference $(\mathrm{P} \leq 0.05)$

They found that Of the spices tested, only oregano at 1.0, 1.5, 2.0\% (w/v) levels showed effect on all fungi. Oregano essential oil, thymol or carvacrol at concentrations of $0.025 \%$ and $0.05 \%$ completely inhibited the growth of all tested fungi, Aspergillus flavus, A. niger, Geotricum candidum, Mucor spp. and Penicillium roqueforti. Also, El-Toony et al. (2003) studied the biochemical reaction of onion, garlic, eucalyptus, caraway, fennel, black cumin, mustard, carnation, neemix and trilogy essential oils against mycelial growth of Rhizoctonia solani and Pythium debaryanum in vitro. They found that complete inhibition of both fungi was obtained by only carnation oil at $4 \%$, however, considerable inhibition (more than 90\%) was obtained with neemix and trilogy oils. Furthermore, El-Mougy et al. (2007) reported that $4 \%$ of the tested essential oils of geranium, rose, lemon and mint had an inhibitory effect against the mycelial growth of $R$. solani and $F$. oxysporum f. sp. phaseoli under in vitro, causing complete inhibition in fungal growth. Recently, there has been considerable demand for the discovery of new natural antimicrobials 
(Sagdic et al. 2003). Plant products with antimicrobial properties have notably obtained attention as possible applicants in order to prevent bacterial and fungal growth (Lanciotti et al. 2004). Plant products are characterized as having a wide range of volatile compounds. This means that essential oils could be used as alternative antibacterial and antifungal treatments (Jenny 2000). It is evident from reviews by Karapinar (1985) and Nanir \& Kadu (1987) that some plant extracts and essential oils exhibited antifungal properties. Kumar \& Tripathi (1991) mentioned that extracts of Eupartorium cannabinum completely inhibited the mycelial growth of Pythium debaryanum, $R$. solani and Sclerotium rolfsii. Furthermore, Juglal et al. (2002) studied the effectiveness of nine essential oils to control the growth of mycotoxin producing moulds and noted that, clove, cinnamon and oregano oils were able to prevent the growth of Aspergillus parasiticus and F. moniliforme. Thyme oil proved to be extremely effective as a fumigant as well as a contact fungicide against a range of the economically significant fungi Alternaria spp., Aspergillus spp., Botrytis cinerea and Erysiphe graminis (Alefyah \& Avice 1997). In other work with bananas, Thangavelu et al. (2004) showed that extracts of Solanum torvum, Jatropha glandulifera and Emblica officinalis were highly inhibitory to mycelial growth of $C$. musaeand the inhibitory effect was directly related to the quantity of extract added to the medium. Also, Thymus vulgaris and Saturegahortensis essential oils had the highest effect on fungal growth with minimum inhibition concentrations of 200 and 400 ppm. These essential oils have high fungicidal effect to control fungal post-harvest diseases of citrus crops (Fatemi et al. 2011).

\section{In vivo efficacy of essential oils treatments against crown rot disease incidence and severity during storage}

After spraying with essential oils, mature bananas artificially inoculated with $F$. semitectum were stored for 21 days and then examined for crown rot incidence and severity. Results presented in Table (3) show that, both crown rot disease incidence and severity were reduced by increasing concentration of essential oils. At the concentration of $4.0 \%$ cinnamon and thyme oils caused a complete reduction (100.0\%) of crown rot disease incidence of banana fruits, followed by sweet almond and bitter almond oils which reduced disease incidence by 87.1 and $78.7 \%$, respectively. Thyme and sweet almond oils at the lowest concentration $(1 \%)$ revealed crown rot incidence recorded as 13.3 and $26.0 \%$ comparing with high records of 40.0 and $40.8 \%$ of treated bananas with cinnamon and bitter almond, respectively. A similar trend was also observed concerning crown rot severity (Table 4). Banana treated with cinnamon and thyme oils at high concentration of $4.0 \%$ caused $100 \%$ reduction in crown rot disease severity, while bitter and sweet almond oils caused a highly significant reduction of 86.7 and $97.4 \%$, respectively, at the same concentration. The reduction in disease severity was $85.4,83.4,70.0$ and $66.7 \%$ at the concentration of $2 \%$ of sweet almond, cinnamon, thyme and bitter almond, respectively. Essential oils of Cymbopogon nardus, Cymbopogon flexuosus and $O$. basilicum have been used to control postharvest diseases of banana while maintaining quality (Anthony et al. 2003). Maqbool et al. (2010) reported that, different concentrations of cinnamon oil did not only delay the onset of anthracnose disease in Panama banana fruits but also maintained the freshness during first two weeks of storage and later on showed minimal symptoms. The highest fungicidal effect was observed in those bananas treated with $0.4 \%$ cinnamon oil, which revealed a disease incidence of $8.0 \%$ and disease severity of 1.0$1.2 \%$. Cinnamon and clove oils have been previously used to control the postharvest fungal pathogens $C$. musae, L. theobromae and $F$. proliferatum in vitro, which were isolated from bananas, with minimum lethal concentrations of $0.08-0.11 \%$ (v/v) (Ranasinghe et al. 2002). Moreover, essential oils of cinnamon and clove contain compounds such as cinnamaldehyde and eugenol, respectively, which have been successfully tested on fresh fruits such as mandarin, kiwi and rambutan to control post-harvest diseases caused by fungi (Arras 1988, Thanassoulopoulos and Yanna 1997, Sivakumar et al. 2002). The mode by which microorganisms are inhibited by essential oils and their chemical compounds seem to involve different mechanisms. It has been hypothesized that the inhibition involves phenolic compounds, because these compounds sensitize 
Table 4 In vivo banana crown rot disease incidence and severity and reduction (\%) in response to fruit coating with different concentrations of some essential oils

\begin{tabular}{|c|c|c|c|c|c|}
\hline Essential oils & $\begin{array}{l}\text { Concentrations } \\
(\%)\end{array}$ & $\begin{array}{l}\text { Disease incidence } \\
(\%)\end{array}$ & $\begin{array}{c}\text { Reduction } \\
(\%)\end{array}$ & $\begin{array}{c}\text { Disease severity } \\
(\%)\end{array}$ & $\begin{array}{c}\text { Reduction } \\
(\%)\end{array}$ \\
\hline & 1 & $40.0 \mathrm{c}$ & 48.7 & $66.6 \mathrm{c}$ & 33.4 \\
\hline \multirow[t]{3}{*}{ Cinnamon } & 2 & $20.0 \mathrm{~d}$ & 74.3 & $16.6 \mathrm{~g}$ & 83.4 \\
\hline & 4 & $00.0 \mathrm{~g}$ & 100.0 & $00.0 \mathrm{~h}$ & 100.0 \\
\hline & 1 & $13.3 \mathrm{e}$ & 82.9 & $53.3 \mathrm{~d}$ & 46.7 \\
\hline \multirow[t]{3}{*}{ Thyme } & 2 & $33.3 \mathrm{f}$ & 95.7 & $30.0 \mathrm{e}$ & 70.0 \\
\hline & 4 & $00.0 \mathrm{f}$ & 100.0 & $00.0 \mathrm{~h}$ & 100.0 \\
\hline & 1 & $40.8 \mathrm{c}$ & 47.6 & $55.0 \mathrm{~d}$ & 45.0 \\
\hline \multirow[t]{2}{*}{ Bitter almond } & 2 & $21.0 \mathrm{~d}$ & 73.0 & $33.3 \mathrm{e}$ & 66.7 \\
\hline & 4 & $16.6 \mathrm{e}$ & 78.7 & $13.3 \mathrm{f}$ & 86.7 \\
\hline \multirow[t]{3}{*}{ Sweet almond } & 1 & $26.0 \mathrm{~d}$ & 66.6 & $41.6 \mathrm{e}$ & 58.4 \\
\hline & 2 & $19.9 \mathrm{~d}$ & 74.4 & $14.6 \mathrm{f}$ & 85.4 \\
\hline & 4 & $10.0 \mathrm{e}$ & 87.1 & $2.6 \mathrm{~h}$ & 97.4 \\
\hline Untreated control & & $78.0 \mathrm{a}$ & ------ & $100.0 \mathrm{a}$ & ------ \\
\hline
\end{tabular}

Figures in each column with the same letter are not significant difference $(\mathrm{P} \leq 0.05)$

the phospholipid bilayer of the microbial cytoplasmic membrane causing increased permeability and unavailability of vital intracellular constituents (Juven et al. 1994). Reports indicated that essential oils containing carvacrol, eugenol and thymol (phenolic compounds) had the highest antibacterial performances (Kim et al. 1995).

\section{Organoleptic properties}

The sensory evaluation of organoleptic properties is shown in Table 5, e.g. odour, flavour, taste and overall acceptability of oil-treated banana when stored at $20-23^{\circ} \mathrm{C}$ and relative humidity of $70-85 \%$. Bananas treated with thyme oil showed lower significant organoleptic properties comparing with other applied essential oils as well as control. Meanwhile, the other essential oil treatments had no significant effect on any organoleptic properties of ripe stored bananas. The values obtained for odour, flavor, taste and overall acceptability were significantly lower for bananas treated with thyme oil when they were compared with other treatments. Bananas treated with cinnamon, bitter and sweet almond oils showed no significant differences compared with the control.

The other essential oil treatments had no significant effect on any organoleptic properties of ripe stored bananas. The mean values for odour, flavour, taste, and overall acceptability could be arranged in descending order as $88.6,88.0,87.3$ and $74.1 \%$ for bananas treated with cinnamon, bitter almond, sweet almond and thyme oils, respectively compared to $92.8 \%$ in untreated control bananas. Similar results were reported by Abeywickrama et al. (2004). The mean values for odour, flavour, taste, and overall acceptability could be arranged in descending order as 88.6, 88.0, 87.3 and $74.1 \%$ for bananas treated with cinnamon, bitter almond, sweet almond and thyme oils, respectively compared to $92.8 \%$ in untreated control bananas.

Similar results were reported by Abeywickrama et al. (2004). Acceptability was significantly lower for bananas treated with thyme oil when they were compared with other treatments. Bananas treated with cinnamon, bitter and sweet almond oils showed no significant differences compared with the control. The other essential oil treatments had no significant effect on any organoleptic properties of ripe stored bananas. The mean values for odour, flavour, taste, and overall acceptability could be arranged in descending order as $88.6,88.0,87.3$ and $74.1 \%$ for bananas treated with cinnamon, bitter almond, sweet almond and thyme oils, respectively compared to $92.8 \%$ in untreated control bananas. Similar results were reported by Abeywickrama et al. (2004). They stated that according to the organoleptic evaluations, no significant difference was observed between the treatments as observed by the panelists. Bananas treated with oil citral and sodium bicarbonate as well as bananas in controls were ranked good 50-75\% to excellent $75-100 \%$ 
Table 5 Sensory evaluation of bananas after treatment with different essential oils stored at 20$23^{\circ} \mathrm{C}$ and relative humidity of $70-85 \%$ for 14 days

\begin{tabular}{llcccc}
\hline Essential oils Treatment & \multicolumn{3}{c}{ Acceptability } & Mean \\
& Odour & Flavour & Taste & Overall acceptability & \\
\hline Cinnamon & $86.2^{*} \mathrm{a}$ & $87.4 \mathrm{a}$ & $90.0 \mathrm{a}$ & $90.8 \mathrm{a}$ & 88.6 \\
Thyme & $70.3 \mathrm{~b}$ & $71.2 \mathrm{~b}$ & $75.8 \mathrm{~b}$ & $79.2 \mathrm{bc}$ & 74.1 \\
Bitter almond & $86.4 \mathrm{a}$ & $88.2 \mathrm{a}$ & $87.3 \mathrm{ab}$ & $90.3 \mathrm{a}$ & 88.0 \\
Sweet almond & $88.6 \mathrm{a}$ & $88.2 \mathrm{a}$ & $86.3 \mathrm{ab}$ & $86.2 \mathrm{ab}$ & 87.3 \\
Untreated control & $89.0 \mathrm{a}$ & $98.3 \mathrm{a}$ & $92.3 \mathrm{a}$ & $91.8 \mathrm{a}$ & 92.8 \\
\hline
\end{tabular}

Each data point represents the mean of ten replicates.

Different letters in the same column denote a significant difference $(\mathrm{P} \leq 0.05)$

with respect to odour, flavour, taste and overall acceptability. They conclude that banana treated with compounds classified as "Generally Regarded As Safe" (GRAS) will be more acceptable to consumers than banana treated with citral and sodium bicarbonate as being used in many industries due to their food preservative action by controlling microorganisms. The low disease severity of crown rot during combined treatment of citral and sodium bicarbonate highlights the importance in adapting this simple, alternate treatment strategy. This finding is supported by previous similar research of organoleptic evaluation of embul banana treated with oils from $O$. basilicum and $C$. flexuosus (Anthony et al. 2003). Goubran \& Holmes (1993) stated that cinnamaldehyde, the major component of cinnamon bark oil, is considered as a generally safe compound and the mammalian toxicity observed for this compound was very low (ID50;2200 mg/kg). In addition, volatile compounds from plants can inhibit the growth of fungal pathogens before evaporating without leaving any residue. Some of them are normal constituents of the human diet and are unlikely to be of any health risk (Hamilton-Kemp et al. 2000).

Hence cinnamon, thyme, bitter and sweet almond oils treatment developed during the current study could be recommended commercially as a safe method for treating bananas to control crown rot disease. The need for such alternative control methods for plant diseases has become more important due to the development of pathogen resistance to the active ingredients of some conventional fungicides as well as increasing restrictions on the types and quantities of these fungicides permitted for use on fruits. Moreover, application of essential oils is an applicable, safe and cost-effective method for controlling such post-harvest diseases. Also, the use of essential oils in agriculture could be a suitable alternative for inclusion in disease control systems and could act sometimes as main or antimicrobial adjuvant without leaving a toxic residue in the product.

\section{References}

Abeywickrama K, Kularathna L, Sarananda K, Abeygunawardena D. 2004 Cymbopogoncitratus (lemongrass) and citrala+b spray treatments alone or in combination with sodium bicarbonate in controlling crown rot in embul banana (Musa acuminataAAB). Tropical Agricultural Research Extension 7, 104-111.

Akgul A, Kivanç M.1988- Inhibitory effect of selected Turkish spices and oregano components on some foodborne fungi. International Journal of Food Microbiolgy 6, 263-268.

Alefyah A, Avice MH. 1997- The fungicidal properties of plant extracts and essential oils. Plant Pathology-Global Perspectives of an Applied Science.E:IpotatolThe BSPP-Archives-BSPP Presidential Meeting 1997.htm (Offered Poster).

Anthony S, Abeywickrama K, Dayananda R, Wijeratnam SW, Arambewela L. 2004 - Fungal pathogens associated with banana fruit in Sri Lanka, and their treatment with essential oils. 
Mycopathologia 157, 91-97.

Anthony S, Abeywickrama K, Wijeratnam SW. 2003 - The effect of spraying essential oils of Cymbopogonnardus, Cymbopoganflexuosus and Ocimumbasilicum on postharvest diseases and storage life of Embul banana. Journal of Horticultural Science Biotechnology 78, 780785.

Arras G. 1988 - Antimicrobial activity of various essential oils and their isolates for blue mould decay control in Citrus reticulata Blanco. Journal ofFood Science Technology 14, 14-16.

Barnett HL, Hunter BB. 1972 - Illusterated Genera of imperfect Fungi.Burgan Publ. Co., Minnesota. 241pp.

Cox JR. 1996 - Postharvest treatment of bananas in the Windward Islands. Pests and Diseases1, 373-378.

Dionisio GA, NatsuakiKT. 2007 - Control of crown rot-causing fungal pathogens of banana by inorganic salts and a surfactant. Crop Protection26(11), 1667-1673.

Don-Pedro KN. 1996 - Fumigant toxicity is the major rout of insecticidal activity of citrus peel essential oils. Pesticide Science 46, 71- 78.

El-MougyNS, El-Gamal NG, Abdel-Kader MM. 2007 - Control of wilt and root rot incidence in Phaseolus vulgaris L. by some volatile compounds. Journal of Plant Protection Research 47 (3), 255-265.

El-Toony AME, Awad NGH, Tadrous MFI. 2003 - Chemical and biochemical control of tomato damping-off disease under nursery conditions with special reference to the antagonism between the causal pathogens. Egyptian Journal of Applied Science 18, 47-68.

Fatemi S, Jafarpour M, Eghbalsaied S, Rezapour A, Borji H. 2011 - Effect of essential oils of Thymus vulgaris and Menthapiperita on the control of green mould and postharvest quality of CitrusSinensiscv. Valencia. African Journal of Biotechnology10 (66), 14932-14936.

Finlay AR, Brown AE. 1993 - The relative importance of Colletotricummusae as a crown-rot pathogen on Windward Island bananas. Plant Pathology 42, 67-74.

Goubran FH, Holmes RJ. 1993 - The Development of Alternative Fungicides from Essential Oils. A Final Report Prepared for the Rural Industries R\&D Corporation. Knoxfield, Victoria: Department of Agriculture, Institute for Horticultural Development. 2008 Rural Industries Research and Development Corporation Electronically published in 2008. New ISBN number: 1741516986 Pub. No.08/110 https://rirdc.infoservices.com.au/downloads/08-110.

Griffee PH. 1976 - Pathogenicity of some fungi isolated from diseased crowns of banana hands. Phytopathology Z 85, 206-216.

Griffee PJ, Burden OJ 1976 - Fungi associated with crown rot of boxed bananas in Windward Islands. Phytopathology Z 85, 149-158.

Griffee PJ, Burden OJ. 1976 - Fungi associated with crown rot of boxed bananas in the Windward Islands. Phytopathology 85(2), 149-158.

Hamilton-Kemp TR, Archbold DD, Andersen RA, Mccracken CT, Collins RW, Fallik K. 2000 Stimulation and inhibition of fungal pathogens of plants by natural volatile phytochemicals and their analogs. Phytochemistry 4, 95-104.

Indrakeerthi SRP, AdikaramNKB. 2011 - Control of crown rot of banana using Carica papaya latex. J. Natn. Sci. Foundation Sri Lanka 39 (2), 155-162.

Jenny J. 2000 - Essential oils: A new idea for postharvest disease control. Good Fruit and Vegetables magazine 11 (3), p. 50. http://postharvest.com.au/GFV_oils.PDF

Jimenez M, Logrieco S, Bottalico A. 1993 - Occurrence and pathogenicity of Fusariumspecies in banana fruits. Journal of Phytopathology137 (3), 214-220.

Johanson A, Blazquez B. 1992 - Fungi associated with crown rot on field-packed fruit from the Windward Islands and assessment of their sensitivity to the fungicides thiabendazole, prochlornaz and imazalil. Crop Protection 11, 79-83.

Jones DR, Slabaugh WR. 1998 - Banana diseases caused by fungi. In: Ploetz RC, Zentmyer GA, Nishijima WT,.Rohrbach KG, Ohr HD (Eds) Compendium of Tropical Fruit Diseases. The American Pathological Society, St. Paul, Minnesota, USA. 
Jones DR. 1991 - Chemical control of crown rot in Queensland bananas. Australian Journal of Experimental Agriculture 31, 693-698.

Juglal S, Govinden R, Odhav B. 2002 - Spices oils for the control of co-occurring mycotoxinproducing fungi. Journal of Food Protection 65, 638-687.

Juven BJ, Kanner J, Sched F, Weisslowicz H. 1994 - Factors that interact with the antibacterial of thyme essential oil and its active constituents. Journal of Applied Microbiology 76, 626631.

Karapinar M. 1985 - The effects of citrus oil and some Turkish spices on growth and aflatoxin production by Aspergillus parasiticus NRRL 2999. International Journal of Food Microbiology 12, 239-245.

Khan SH, Aked J, Magan N. 2001- Control of the anthracnose pathogen of banana (Colletotrichum musae) using antioxidants alone and in combination with thiobendazole or imazalil. Plant Pathology 50(5), 600-608.

Kim J, Marshall MR, Wei C. 1995 - Antibacterial activity of some essential oils components against five foodborne pathogens. Journal of Agriculture and Food Chemistry 43, 28392845.

Knight C. 1982 - Pathogenicity of some fungi associated with crown rot of bananas. Phytopathology Z 89, 170-176.

Kumar A, Tripathi SC. 1991- Evaluation of the leaf juice of some higher plants for their toxicity against soilborne pathogens. Plant and Soil 132, 297-301.

Lanciotti R, Gianotti A, Patrignani N, Belleti N, Guerzoni ME, Gardini F. 2004 - Use of natural aroma compounds to improve shelf-life of minimally processed fruits. Trends of Food Science and Technology 15, 201-208.

Lassois L, de Lapeyre de Bellaire L, Jijakli MH. 2008 - Biological control of crown rot of bananas with Pichiaanom alastrain K and Candida oleophila strain. Biological Control45(3), 410418.

Liu ZL, Ho SH. 1999 - Bioactivity of the essential oil extracted from Evodiaruta ecarpa Hook f. et Thomas against the grain storage insects, Sitophilus zeamais Motsch. And Tribolium castaneum (Herbst.). Journal of Stored Product Research 35, 317-328.

Lukezic FL, Kaiser WJ, Martinez MM. 1967 - The incidence of crown rot of boxed bananas in relation to microbial populations of the crown tissue. Canadian Journal of Botany 45, 413421.

Maqbool M, Ali A, Alderson PG. 2010 - Effect of cinnamon oil on incidence of anthracnose disease and postharvest quality of bananas during storage. International Journal of Agricultural Biology 12, 516-520.

Meredith DS. 1971 - Transport and storage diseases of bananas: biology and control. Tropical Agriculture 48, 35-50.

Montes-Belmont R, Carvajal M. 1998 - Control of Aspergillus flavus in maize with plant essential oils and their components. Journal of Food Protection 61(5), 616-619.

Nanir SP, Kadu BB. 1987 - Effect of some medicinal plants extract on some fungi. Acta Botanica India 15, 170-175.

Neler J, Wasserman W, Kutner MH. 1985 - Applied Linear Statistical Models, Regression Analysis of Variance and Experimental Design. 2nd ed. Richard, D. Irwin Inc. Hame Wood Illinois. $1127 \mathrm{pp}$.

Paranagama PA, Abeysekera KHT, Abeywickrama K, Nugaliyadd L. 2003 - Fungicidal and antiaflatoxigenic effects of the essential oil ofCymbopogoncitratus (DC.)Stapf. (lemongrass) against AspergillusflavusLink. isolated from stored rice. Letters of Applied Microbiology 37, 86-90.

Paster N, Menasherov M, Ravid U, Juven B. 1995 - Antifungal activity of oregano and thyme essential oils applied as fumigants against fungi attacking stored grain. Journal of Food Protection 58, 81-85. 
Ranasinghe L, Jayawardena B, Abeywickrama K. 2002 - Fungicidal activity of essential oils of Cinnamomum zeylanicum (L.) and Syzygium aromaticum (L.) MerretL. M. Perry against crown rot and anthracnose pathogens isolated from banana. Letters of Applied Microbiology $35,208-211$.

Ranasinghe L, Jayawardena B, Abeywickrama K. 2005 - An integrated strategy to control postharvest decay of Embul banana by combining essential oils with modified atmosphere packaging. International Journal of Food Science and Technology 40, 97-103.

Sagdiç O, Karahan AG, Ozcan M, Ozcan G. 2003 - Effect of some spices extracts on bacterial inhibition. International Journal of Food Science and Technology9, 353-359.

Sarananda KH, Wijeratnam RSW. 1994 - Controlled atmosphere storage of Embul bananas. Tropical Agriculture Research 6, 17-22.

Shillingford CA. 1976 - Occurrence of banana fruit rot fungi in Jamaican boxing plants. Plant Disease Reporter 66 (9), 788-793.

Shillingford CA. 1977 - Control of banana fruit rots and of fungi that contaminate washing water. Tropical Science 19, 197-203.

Sivakumar D, Wilson WS, Wijesundara RLC, and Abeysekere M. 2002 - Combined effect of generally regarded as safe (GRAS) compounds and Trichoderma harzianum on the control of postharvest diseases of Rambutan. Phytoparasitica 30, 43-51.

Slabaugh WR, Grove MD. 1982 - Postharvest diseases of bananas and their control. Plant Disease 66, 746-750.

Stover RH. 1972 - Banana, plantation and abaca diseases. Commonwealth Agricultural Bureaux, London.

Sutton BC. 1980 - The Coelomycetes. Common Wealth Mycological Institute, Kew. pp. 696.

Thanassoulopoulos CC, Yanna L, 1997 - On the biological control of Botrytis cinerea on kiwifruit cv. Hayward during storage.Acta Horticulture 444, 757-762.

Thangavelu R, Sundararaju P, Sathiamoorthy S. 2004 - Management of anthracnose disease of banana caused by Colletotrichum musae using plant extracts. Journal of Horticultural Science Biotechnology 79, 664-668.

Vesonder RF, Logrieco S, Bottalico A, Altomare C, Peterson SW. 1995 - Fusarium species with banana fruit rot and their potential toxigenixity. Mycotoxin Research 1(2), 93-98.

Wallbridge A, Pinegar JA. 1975 - Fungi associated with crown rot disease of bananas from St. Lucia in Windward Islands. Transaction of British Mycological Society 64, 247-254.

Wallbridge A. 1981 - Fungi associated with crown rot disease of boxed bananas from the Windward Islands during a two-year survey. Transaction of British Mycological Society 77, 567-577.

Wijesekara ROB, Ratnatunga CM, Durbeck K. 1997 - The distillation of essential oils. Manufacturing and Plant Construction Handbook Eschborn. Federal Republic of Germany: Protrade, Department of Foodstuffs and Agricultural Products. www.naturalproduct.us/content/npc-2-12-2007.pdf 